\title{
Characteristic of Tobacco mosaic virus isolated from cucumber and tobacco collected from East Java, Indonesia
}

\author{
LISTIHANI, SRI HENDRASTUTI HIDAYAT, SURYO WIYONO, TRI ASMIRA DAMAYANTI \\ Department of Plant Protection, Faculty of Agriculture, Institut Pertanian Bogor. Jl. Kamfer, Kampus IPB Darmaga, Bogor 16680, West Java, Indonesia. \\ Tel./fax.: +62-251-8629353, `email: triadys@ apps.ipb.ac.id
}

Manuscript received: 22 July 2019. Revision accepted: 14 September 2019.

\begin{abstract}
Listihani, Hidayat SH, Wiyono S, Damayanti TA. 2019. Characteristic of Tobacco mosaic virus isolated from cucumber and tobacco collected from East Java, Indonesia. Biodiversitas 20: 2937-2942. Tobacco mosaic virus (TMV) is a newly emerging virus infecting cucumbers in Java, Indonesia. The basic characters of the TMV isolated from cucumber need further study to investigate its differences with that from tobacco. Thus, the research aimed to study the character of both isolates based on their biological, symptomatology and nucleic acid of coat protein $(\mathrm{CP})$ gene properties. The TMV isolates from both cucumber and tobacco were able to infect similar indicator plants with differing symptom expressions, especially on eggplant. Homology of nucleotide and amino acid of coat protein gene among isolates were about $90.3 \%$ and $91.0 \%$, and homology to other isolates was about 87.6 to $93.8 \%$ and 89.3 to $96.8 \%$, respectively. There were 17 amino acid differences in the CP gene which is presumed to differentiate those two isolates. Phylogenetic analysis CP gene sequences compared with corresponding isolates in GenBank showed the two isolates separated in different clades. The cucumber isolate from Kediri is closely related to tomato isolate from China in clade I, while tobacco isolate from Jember closely related to tobacco isolate from China in clade II, indicating the existence of two differ TMV variants. It will increase the difficulty to manage TMV in the fields.
\end{abstract}

Keywords: Cucurbitaceae, diagnosis, diversity, tobamovirus

\section{INTRODUCTION}

Cucumber is one of essential vegetables that is widely consumed by the people of Indonesia. Besides, it is used as a cosmetic ingredient. Cucumbers are planted in almost all parts of Indonesia, such as Sumatra, Java, Kalimantan, Sulawesi, Bali, Nusa Tenggara, Maluku, and Papua (Central Bureau of Statistics 2017). Among these areas, cucumber plants are mostly cultivated in Java Island. In previous studies, cucumbers in Java were reported to be infected by seven viruses such as Cucumber mosaic virus, Cucurbit aphid-borne yellows virus, Papaya ringspot virus, Squash mosaic virus, Tobacco mosaic virus, Tomato yellow leaf curl New Delhi virus, and Zucchini yellow mosaic virus based on serology test. The distribution of those viruses was prevalence in Java with virus frequency varied depends on sampling locations and cultivars in the fields (Listihani et al. 2018).

Tobacco mosaic virus (TMV) is a typical member of Tobamovirus in the family Virgaviridae. The virion is a rigid rod particle with a size of about $18 \mathrm{~nm}$ x $300 \mathrm{~nm}$ containing a single strand RNA (ICTV 2012; Koch et al. 2015). The virions often form a large crystalline structure shown in a light microscope (ICTV 2012). TMV can be transmitted mechanically through splicing and contact between plants and seeds. Yet, until present, there is no insect known as vector. TMV has a broad host range in the families Solanaceae, Brassicae, Cucurbitaceae, and some ornamental plants (Choi et al. 2009; Kumar et al. 2011; Nassar et al. 2012; Khamphirapaeng et al. 2017).
Tobamovirus members are known to infect mostly solanaceous and able to cause serious yield losses in many crops. TMV infection on pepper cause yield loss of about $90 \%$, up to $59 \%$ on tomato fruit and $24 \%$ on tobacco (Johnson and Main 1983; Cherian and Muniyapppa 1998; Chitra et al. 2002). Despite the significant impacts of TMV in vegetable crops, there is little information available related to its basic characteristics as well as its genetic and variability, including TMV isolated from tobacco in Indonesia.

Cucumber green mottle mosaic virus and Kyuri green mottle mosaic virus were reported to infect melon and ridged gourd in Yogyakarta (Daryono and Natsuaki 2009), while TMV had been reported to infect solanaceous such as tobacco, chili pepper and tomato (Balique et al. 2012; Damiri 2014; Mahendra et al. 2017) and also infect orchid (Somowiyarjo et al. 2016) in Indonesia. Recently, we reported the first occurrence of TMV infection on cucumber collected from several cucumber cultivations in Java with frequency ranged from 5.5-24.4\% based on serological test (Listihani et al. 2018). Although TMV was previously reported to infect solanaceous and orchid, most studies focused on serological detection. Whereas, the basic characters of TMV cucumber isolate, as well as solanaceous isolates such as type of symptoms on many different hosts and the genetic differences of those isolates, was not reported so far. Therefore, here we reported the basic characters of TMV isolated from cucumber collected from Kediri compared to TMV isolated from tobacco collected from Jember, East Java, Indonesia. 


\section{MATERIALS AND METHODS}

\section{Source of inoculum}

TMV cucumber isolate was obtained from Kediri while TMV tobacco isolate was from Jember, both are districts in East Java. TMV was isolated by mechanical inoculation on Nicotiana glutinosa plants. The necrotic local lesion (NLL) were collected and used as inoculum to infect $N$. glutinosa. Similar step was conducted twice. The last NLL was used as inoculum to propagate TMV on $N$. tabacum according to the procedure described by Adkins et al. (2003).

\section{Biological assays on indicator plants}

Biological assay was conducted by mechanical inoculation of TMV isolates onto leaves of test plants. Symptom observation on indicator plants was conducted using 17 plant species from 6 families namely Lycopersicum esculentum, Nicotiana tabacum, $N$. glutinosa, N. benthamiana, Capsicum annum, Solanum melongena, Cucumis sativus, C. melo, Cucurbita moschata, Citrullus lanatus, Phaseolus vulgaris, Vigna sesquipedalis, Glycine max, Gomphrena globosa, Chenopodium amaranticolor, Ageratum conyzoides, and Oxalis barrelieri. Sap was prepared by ground the symptomatic leaves inoculum in $0.025 \mathrm{M}$ phosphate buffer $\mathrm{pH} 7.0$ containing $1 \% \beta$-mercaptoethanol and the sap was rubbed onto leaves of the test plants, previously dusted with carborundum 600 mesh. All test plants were grown in greenhouse. The symptom types were observed every day until a month post-inoculation.

\section{RT-PCR, cloning, and sequencing of TMV CP gene}

A total RNA was extracted from symptomatic plants using the CTAB method (Doyle and Doyle 1987) with minor modification in lysis step shorter at $65{ }^{\circ} \mathrm{C}$, from 60 min to $30 \mathrm{~min}$. The cDNA was synthesized from total RNA using Moloney Murine Leukemia Virus (M-MuLV) according to the protocol provided by Thermo Fisher Scientific, USA. RT-PCR reaction was carried out in a 25 $\mu \mathrm{l}$ mixture containing $12.5 \mu \mathrm{l}$ Go Taq Green (Thermo Fisher Scientific, USA), $1 \mu \mathrm{l}$ cDNA template, $1 \mu \mathrm{l}$ of the primers $(10 \mu \mathrm{M})$ for each, and $9.5 \mu \mathrm{l}$ ddH2O. Amplification of the cDNA was carried out using a pair of universal primer for Tobamovirus. The expected size of the RT-PCR product was \pm 800 bp (Letschert et al. 2002).

The amplified DNA products were analyzed on $1 \%$ agarose gel electrophoresis in 0.5X TBE buffer containing nucleic acid staining dye FlouroVue TM (Smobio, Taiwan). The PCR product directly cloned into TA cloning vector $\mathrm{pTZ} 57 \mathrm{R} / \mathrm{T}$ according to protocol provided by Thermo Fisher Scientific (USA). The plasmid DNA of positive clones was extracted according to El-Baky et al. (2013) and sequenced.

\section{Sequences analysis}

Sequences homology of TMV CP gene was compared to corresponding isolates from other countries available in the GenBank database as implemented in the program Bio Edit v7.05. Phylogenetic analysis was constructed by MEGA v6.0 software with the neighbor-joining algorithm and bootstrap value 1000 repetitions (Tamura et al. 2013).

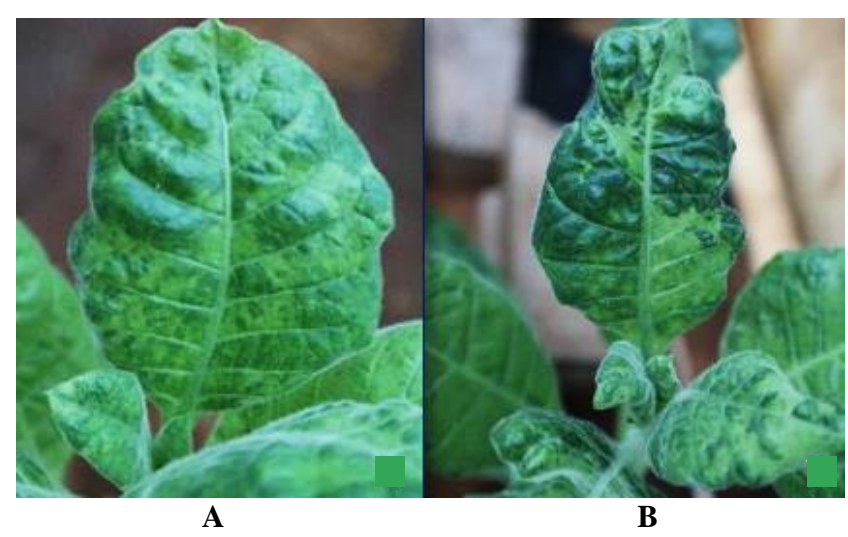

Figure 1. Typical mosaic symptom of TMV: A. Cucumber isolate from Kediri, and B. Tobacco isolate from Jember

\section{RESULTS AND DISCUSSION}

Biological assays on indicator plants showed that the two isolates were able to infect similar indicator plants with varying symptom expressions depending on isolate (Table1). TMV either isolated from cucumber or tobacco systemically infected the members of Solanaceae $(L$. esculentum, $N$. tabacum, N. glutinosa, $N$. benthamiana, $C$. annum), Cucurbitaceae (C. sativus, C. melo, C. moschata, C. lanatus), Fabaceae (P. vulgaris, V. sesquipedalis, G. $\max$ ). However, either isolates induced necrotic local lesion on G. globosa, C. amaranticolor, O. barrelieri and A. conyzoides. The typical symptom of TMV on $N$. tabacum differed. Cucumber isolate caused milder mosaic, while tobacco isolate caused severe mosaic dan leaf malformation (Figure 1). This virus source was used as inoculum for host range test.

The two TMV isolates showed obvious symptom development on S. melongena. Cucumber isolate caused chlorosis spot on infected leaves, while tobacco isolates caused systemic symptoms. It indicates that the two isolates are able to be distinguished on S. melongena. Previous study on TMV cucumber isolate from Bogor, West Java showed that TMV infection on G. globosa, $C$. amaranticolor, C. moschata, and G. max induced chlorotic local lesion symptoms on infected leaves and no symptom on upper leaves (Listihani et al. 2018), while on this study TMV caused necrotic local lesion on G. globosa and A. amaranticolor, while on. C. moschata and G. max caused chlorosis spot on infected leaves and mosaic on upper leaves. This suggests that there are different types of cucumber isolate in Java along with different symptom variations. The symptom differences may be due to the genetic variation among TMV isolates, and geographical locations and/or climatic conditions in Java. Similar case previously occurred on TMV-potato isolates in Korea (Jung et al. 2002). Many different strains of TMV are present in nature, which are different in biological properties (Nassar et al. 2012). These results supported the previous study by Jung et al. (2002) and Alishiri et al. (2013).

TMV cucumber isolate from Kediri caused systemic infections in Cucurbitaceae (C. sativus, C. melo, $C$. 
moschata, C. lanatus) and Fabaceae (P. vulgaris, $V$. sesquipedalis, G. max) with symptoms varied, while TMV Cucurbitaceae isolates from Iran represented by pumpkin isolate (HQ593618) remained symptomless either on infected or upper leaves of C. sativus, V. unguiculata and on Vicia faba caused necrotic local on inoculated leaves and symptomless on upper leaves, but virus was detectable by ELISA and PCR (Alishiri et al. 2013). This indicates that TMV cucumber isolate from Kediri and pumpkin isolate from Iran could infect similar family of indicator hosts with different symptom expressions; Kediri isolate caused obvious symptoms, but Iran isolates did not induce any obvious symptom (symptomless) on those indicator plants. The difference in symptom expressions among those isolates may be caused by the difference in origin of host species rather than genetic variability, because low genetic variation among geographically distant isolates has been reported for other tobamoviruses (Rao et al. 2017; Rakhshandehroo et al. 2018), including TMV isolates in Iran (Alishiri et al. 2013). This study also revealed that experimentally P. vulgaris, V. sesquipedalis, G. max, $C$. melo, $C$. moschata, and $C$. lanatus have potency as additional systemic hosts for the two isolates. Despite these plants have not been reported yet previously as natural hosts of TMV in Indonesia, if TMV infection occurs on those plants naturally, these will implicate increasing impact of TMV on crops production, especially for Cucurbitaceae members such as C. melo, C. moschata, and C. lanatus. O. barrelieri and A. conyzoides are common weeds in crop fields. Those plants caused local chlorotic spot on inoculated leaves (Table 1) and suggested both weeds become a potential reservoir host of TMV in the fields.

In Indonesia, TMV mostly infects solanaceous plants, such as chili pepper, tomato, tobacco, and eggplant. The infection of TMV in cucumber in Java is likely because the cucumbers are cultivated contiguously with tobacco and also some farmers cultivate cucumber after harvesting tobacco in Kediri. In this situation, the tobacco plant residues are likely not eradicated properly, facilitating the presence of TMV in the fields. Infected plant residues remained in the soil may act as source of infection which mechanically transmitted virus for the next crop, especially when the susceptible crops are grown in the same fields. Since TMV is seed-borne mostly on solanaceous and others crops (Dombrovsky and Smith 2017), the majority of growers in Indonesia, especially in Java, use their own seeds of any crops instead of more standardized seeds and this may contribute to the spread of TMV in these crops. Alternatively, the presence of different TMV variant on different host might be caused by host effect on the evolution of this virus (Aldaoud et al. 1989). Experimentally, TMV CP gene is a target of nucleotide substitutions or mutations during continuous passaging/transmission to different hosts. This caused nucleotide shifting following selective disturbance such as extended transmission in those alternative plant as new host (Kearney et al. 1999).
RT-PCR was successfully amplified a DNA with size \pm 800 bp using universal primer of tobamovirus (Figure 2). The amplified fragment encompasses $480 \mathrm{bp}$ of the CP coding region plus sequences of the $5^{\prime}$ and 3 ' flanking regions. As a result of DNA sequencing, the CP TMV gene was successfully sequenced with full-length size $480 \mathrm{nt}$ and encoded 159 amino acids. The nucleotides sequences of two isolates were deposited in GenBank with accession numbers LC311787 and LC3900329. Homology analysis of CP gene sequences showed that TMV cucumber and tobacco isolates showed high similarity to TMV isolates from other countries (Table 2). The homology of nucleotide and amino acids sequences of TMV cucumber and tobacco isolates to corresponding isolates in the GenBank were about 87.6 to $93.8 \%$ and 89.3 to $96.8 \%$, respectively. TMV cucumber isolate from Kediri is close to tomato isolate (JX993906), while the tobacco isolate from Jember is close to tobacco isolate (HE818426) from China. The high similarity among isolates available in GenBank indicates a low genetic diversity.

Comparison of amino acid residues in CP gene of TMV isolates showed 11 amino acids especially for cucumber isolate against others. While TMV cucumber isolate showed that the 17 amino acid residues differ with tobacco isolate (Table 3). The difference symptom expressions in indicator plants might be related to the differences in amino acids since the TMV CP gene is often responsible for differences in symptom development (Conti et al. 2017). The importance of the viral CP in symptom development and in determining host range differences has been shown for tobamovirus-plant combinations (Luria et al. 2017; Li et al. 2017). Further, TMV isolates are differentially selected by different plant species and selective pressure plays an important role in TMV genetic divergence (Gallois et al. 2018). Amino acid residues of cucumber isolate differ with other isolates (Table 3) at position of 50 (E50D) and 77 (D77A). Those two residues in the TMV $\mathrm{CP}$ gene are reported to involve in symptoms of tobacco (Bendahmane et al. 2007).

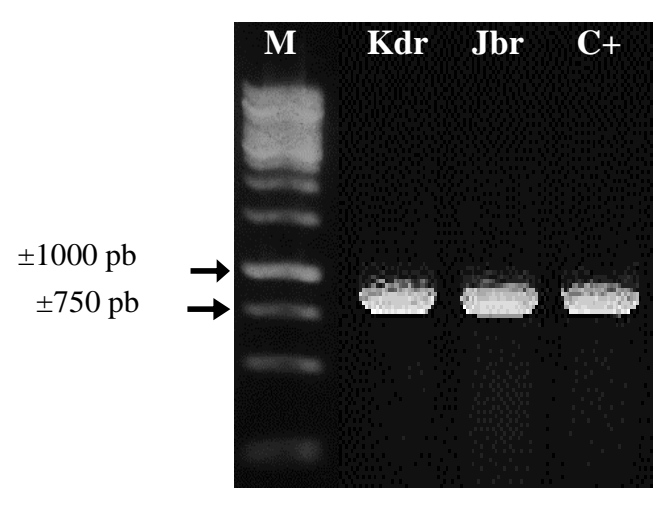

Figure 2. RT-PCR product of $\mathrm{CP}$ gene of TMV Kediri isolate (Kdr) and Jember isolate (Jbr). C+. positive control, M. DNA ladder $1 \mathrm{~kb}$ (Thermo Fisher Scientific, USA) 
Table 1. Symptoms development of TMV cucumber and tobacco isolates on indicator plants

\begin{tabular}{|c|c|c|}
\hline Family/species & $\begin{array}{l}\text { TMV cucumber isolate } \\
\text { Symptoms on I / } \mathrm{S} \\
\end{array}$ & $\begin{array}{r}\text { TMV tobacco isolate } \\
\text { Symptoms on I / S }\end{array}$ \\
\hline \multicolumn{3}{|l|}{ Amaranthaceae } \\
\hline Gomphrena globosa & NLL/- & NLL/- \\
\hline Chenopodium amaranticolor & NLL/- & NLL/- \\
\hline \multicolumn{3}{|l|}{ Solanaceae } \\
\hline Lycopersicum esculentum & NLL/M & NLL/M, Mf \\
\hline Nicotiana tabacum & NLL/M & NLL/M, Mf \\
\hline Nicotiana glutinosa & NLL/M & NLL/M, Mf \\
\hline Nicotiana benthamiana & NLL/M & NLL/M \\
\hline Capsicum annum & NLL/M & NLL/M, Mf \\
\hline Solanum melongena & NLL/- & NLL/M, Mf \\
\hline \multicolumn{3}{|l|}{ Cucurbitaceae } \\
\hline Cucumis sativus & $\mathrm{CS} / \mathrm{M}, \mathrm{Mf}$ & $\mathrm{CS} / \mathrm{M}$ \\
\hline Cucumis melo & $\mathrm{CS} / \mathrm{Mf}$ & $\mathrm{CS} / \mathrm{M}$ \\
\hline Cucurbita moschata & $\mathrm{CS} / \mathrm{M}, \mathrm{Mf}$ & $\mathrm{CS} / \mathrm{M}$ \\
\hline Citrullus lanatus & $\mathrm{CS} / \mathrm{M}, \mathrm{Mf}$ & $\mathrm{CS} / \mathrm{Mf}$ \\
\hline \multicolumn{3}{|l|}{ Fabaceae } \\
\hline Phaseolus vulgaris & $\mathrm{CS} / \mathrm{M}$ & $\mathrm{CS} / \mathrm{M}$ \\
\hline Vigna sesquipedalis & $\mathrm{CS} / \mathrm{M}$ & $\mathrm{CS} / \mathrm{M}, \mathrm{Mf}$ \\
\hline Glycine $\max$ & $\mathrm{CS} / \mathrm{M}$ & $\mathrm{CS} / \mathrm{M}, \mathrm{Mf}$ \\
\hline \multicolumn{3}{|l|}{ Oxalidaceae } \\
\hline Oxalis barrelieri & $\mathrm{CS} /-$ & $\mathrm{CS} /-$ \\
\hline Asteraceae & & \\
\hline Ageratum conyzoides & $\mathrm{CS} /-$ & $\mathrm{CS} /-$ \\
\hline
\end{tabular}

Note: I=inoculated leaves, $\mathrm{S}=$ systemic leaves; $\mathrm{CS}=$ chlorosis spot, $\mathrm{NLL}=$ necrotic local lesions, $\mathrm{Mf}=$ malformation, $\mathrm{M}=\mathrm{mosaic},(-)=$ no symptom and TMV= negatively detected by serological test

Table 2. Homology of nucleotide (nt) and amino acids (aa) CP gene of TMV of two isolates with other isolates in GenBank

\begin{tabular}{llllll}
\hline Strain & \multirow{2}{*}{ Accession number } & Host & \multirow{2}{*}{ TMV isolates } & \multicolumn{2}{c}{ Homology nt (aa) $(\%)$} \\
\cline { 4 - 6 } Vulgare & LC311787 & Cucumber & Indonesia-Kediri & \\
Vulgare & LC390329 & Tobacco & Indonesia-Jember & $90.3(91.0)$ & $90.3(91.0)$ \\
Vulgare & JX93906 & Tomato & China & $93.8(94.9)$ & $91.4(95.0)$ \\
Vulgare & HE818426 & Tobacco & China & $91.2(93.1)$ & $91.8(96.8)$ \\
Vulgare & X68110 & Tobacco & Korea & $93.1(94.7)$ & $91.6(95.0)$ \\
Vulgare & KF972435 & Tobacco & Spain & $93.1(94.5)$ & $91.8(95.0)$ \\
Vulgare & AY360447 & Eggplant & Africa & $93.1(94.7)$ & $91.6(95.0)$ \\
Vulgare & AF273221 & Tobacco & America & $93.1(94.5)$ & $91.4(95.0)$ \\
S & JQ895560 & Soybean & India & $93.1(94.7)$ & $91.6(95.0)$ \\
B & Z96945 & Faba bean & China & $93.1(94.7)$ & $91.6(95.0)$ \\
Vulgare & AJ429078 & Tomato & Germany & $93.1(94.7)$ & $91.6(95.0)$ \\
UI & V01408 & Tomato & Germany & $93.1(94.7)$ & $91.6(95.0)$ \\
Vulgare & AY633749 & Chili pepper & Thailand & $91.2(92.3)$ & $91.2(95.0)$ \\
P & AY029262 & Petunia & Brazil & $91.2(91.4)$ & $91.2(94.3)$ \\
R & D63809 & Allium & Japan & $90.0(93.1)$ & $91.2(91.8)$ \\
Vulgare & HQ593618 & Pumpkin & Iran & $87.6(89.3)$ & $91.2(95.0)$ \\
petTW & EF392659 & Petunia & Taiwan & $63.1(67.2)$ & $66.3(72.2)$ \\
ORSV* & E04305 & Orchid & South Korea & &
\end{tabular}

Note: * ORSV: Odontoglossum ringspot virus isolates South Korea as an outgroup; nt (nucleotide) and aa (amino acid), C=TMV isolates for cucumbers, T=TMV tobacco isolates 
Table 3. Amino acid differences in TMV CP gene among cucumber isolate from Kediri (LC311787) and tobacco isolate from Jember (LC390329) compared with corresponding isolates of tomato (JX993906) and tobacco (HE818426) from China and pumpkin (HQ593618) from Iran

\begin{tabular}{|c|c|c|c|c|c|c|c|c|c|c|c|c|c|c|c|c|c|c|c|c|}
\hline \multirow{2}{*}{ TMV isolates } & \multicolumn{20}{|c|}{ Amino acid different at position } \\
\hline & 4 & 13 & 28 & 45 & 49 & 50 & 65 & 66 & 75 & 77 & 86 & 94 & 97 & 130 & 139 & 142 & 144 & 148 & 149 & 156 \\
\hline LC311787 & $\mathrm{T}$ & $\underline{F}$ & $\underline{\mathbf{R}}$ & $\underline{\mathbf{A}}$ & $\underline{\mathbf{V}}$ & $\underline{\mathbf{D}}$ & $\underline{\mathrm{D}}$ & $\underline{S}$ & $\underline{\mathrm{A}}$ & A & $\underline{\mathbf{R}}$ & $\underline{\mathbf{V}}$ & $\underline{\mathbf{D}}$ & I & $\underline{Y}$ & $\underline{\mathrm{R}}$ & $\underline{\mathrm{S}}$ & $\underline{Y}$ & $\underline{\mathbf{Y}}$ & $\underline{\mathbf{S}}$ \\
\hline LC390329 & $\mathrm{T}$ & $\underline{\bar{Y}}$ & $\overline{\bar{C}}$ & $\underline{\bar{V}}$ & $\underline{\bar{F}}$ & $\overline{\mathrm{Q}}$ & $\underline{\bar{A}}$ & $\underline{\bar{N}}$ & $\underline{\bar{S}}$ & A & $\overline{\mathrm{G}}$ & $\overline{\bar{I}}$ & $\underline{\bar{V}}$ & I & $\underline{\bar{S}}$ & $\overline{\mathrm{Q}}$ & $\underline{\overline{\mathrm{A}}}$ & $\underline{\bar{S}}$ & $\underline{\bar{S}}$ & $\underline{\bar{G}}$ \\
\hline JX993906 & S & $\bar{F}$ & $\overline{\mathrm{C}}$ & $\overline{\mathrm{V}}$ & $\bar{F}$ & $\overrightarrow{\mathrm{E}}$ & $\overline{\mathrm{D}}$ & $\overline{\mathrm{S}}$ & $\overline{\mathrm{A}}$ & $\mathrm{D}$ & $\overline{\mathrm{G}}$ & I & $\overline{\mathrm{V}}$ & V & $\bar{S}$ & $\mathrm{R}$ & $\bar{S}$ & $\bar{S}$ & $\bar{S}$ & $\overline{\mathrm{G}}$ \\
\hline HE818426 & S & Y & $\mathrm{C}$ & V & $\mathrm{F}$ & $\mathrm{E}$ & $\mathrm{D}$ & $\mathrm{N}$ & S & D & $\mathrm{G}$ & I & V & V & S & Q & S & $S$ & S & $\mathrm{G}$ \\
\hline HQ593618 & $\mathrm{S}$ & $\mathrm{F}$ & $\mathrm{C}$ & $\mathrm{V}$ & $\mathrm{F}$ & $\mathrm{E}$ & $\mathrm{D}$ & $\mathrm{S}$ & A & $\mathrm{D}$ & $\mathrm{G}$ & $\mathrm{I}$ & $\mathrm{V}$ & $\mathrm{V}$ & $\mathrm{S}$ & $\mathrm{R}$ & $\mathrm{S}$ & S & $\mathrm{S}$ & $\mathrm{G}$ \\
\hline
\end{tabular}

Note: *as comparison. $\mathrm{A}=$ Alanine, $\mathrm{C}=$ Cysteine, $\mathrm{D}=$ Aspartate, $\mathrm{E}=$ Glutamate, $\mathrm{F}=$ Phenylalanine, $\mathrm{G}=\mathrm{Glycine}, \mathrm{H}=\mathrm{Histidine}, \mathrm{I}=$ Isoleucine, $\mathrm{K}=$ Lysine, $\mathrm{L}=$ Leucine, $\mathrm{M}=$ Methionine, $\mathrm{N}=$ Asparagine, $\mathrm{P}=$ Proline, $\mathrm{Q}=$ Glutamine, $\mathrm{R}=$ Arginine, $\mathrm{S}=\mathrm{Serine}, \mathrm{T}=\mathrm{Threonine}$, $\mathrm{V}=$ Valine, $\mathrm{Y}=$ Tyrosine, Underlines $=$ amino acid differences among cucumber and tobacco isolates from East Java, bold type $=$ amino acid differences among all compared isolates
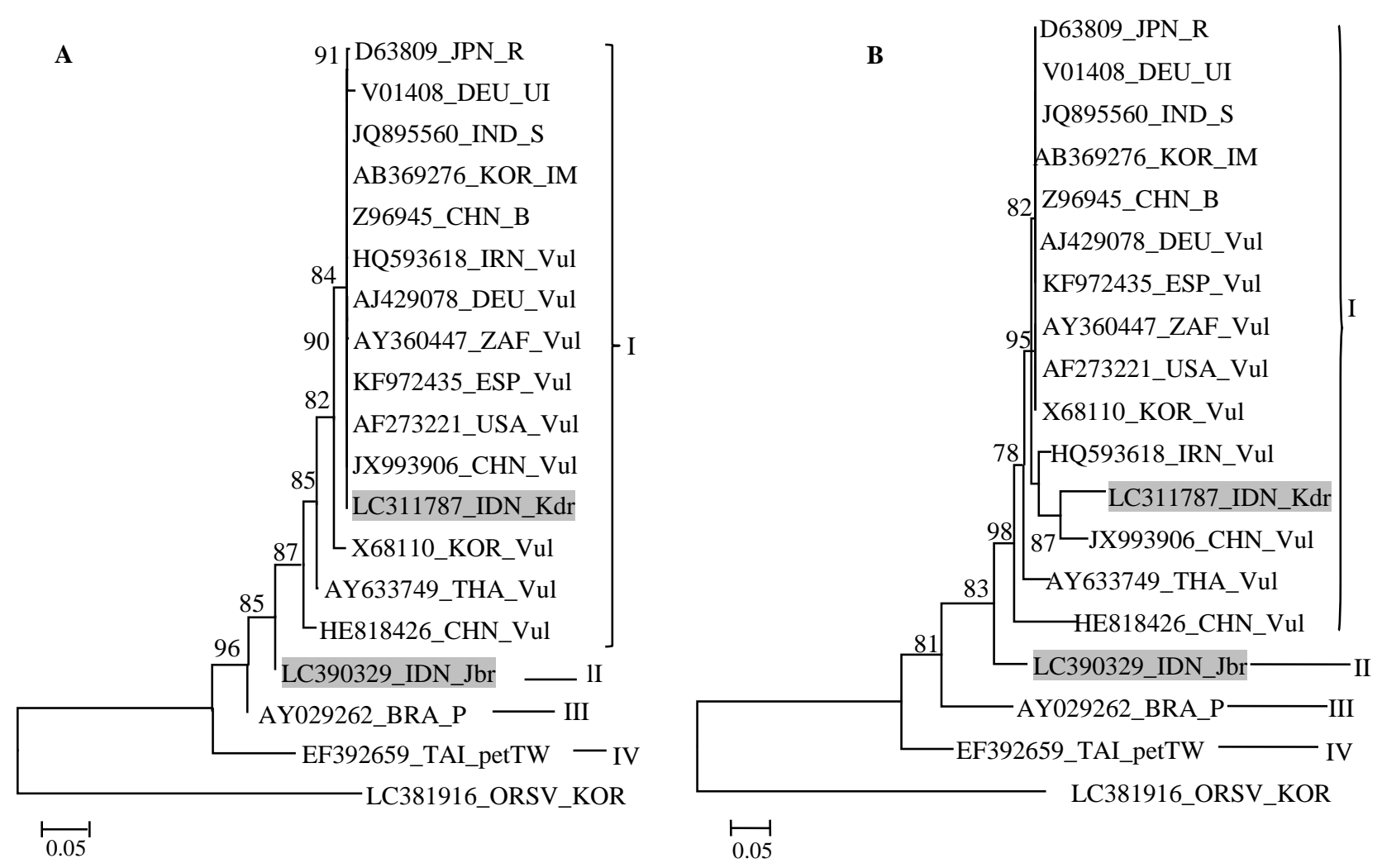

Figure 3. Phylogenetic trees constructed based on: (A) nucleotides; and (B) amino acid sequences of the full-length CP TMV gene of cucumber isolate from Kediri and tobacco isolate from Jember compared to 16 corresponding isolates available in the Genbank. Bootstrap percentages of clades are shown along internal branches of tree. Odontoglossum ringspot tobamovirus (ORSV) was used as an outgroup species. Isolates with grey highlight are cucumber isolate from Kediri and tobacco isolate from Jember. IDN-Indonesia, KORSouth Korea, JPN-Japan, USA-USA, IRN-Iran, CHN-China, ZAF-Africa, DEU-Germany, ESP Spain, TAI-Taiwan, BRA-Brazil, THAThailand, IND-India, Kdr-Kediri, Jbr-Jember. The bar at the bottom left represents 0.05 nucleotide substitutions per site

Phylogenetic analysis showed that TMV cucumber isolate from Kediri was separated in different group with TMV tobacco from Jember. Phylogenetic tree analysis both TMV isolates based on either nucleotide or amino acid sequences compared with corresponding isolates in GenBank database showed that TMV isolates divided into 4 clades. The clade I consist of TMV isolates from Japan, Germany, Africa, India, South Korea, Iran, America, Spain, China, Thailand and cucumber isolate from Kediri, while clade II consists only TMV tobacco isolate from Jember. In clade III is TMV isolate from Brazil, and clade IV is TMV petunia isolate from Taiwan (Figure 3). The results indicated that TMV cucumber isolate from Kediri was closely related with TMV tomato isolate SQFQ from China (JX993906). Whereas, TMV tobacco isolate from Jember was closely to tobacco isolate from Hechi China (HE818426). Both TMV Java isolates belong to TMV strain vulgare. Our results support the previous report by 
Alishiri et al. (2013) that there is no obvious correlation between $\mathrm{CP}$ sequences variation and the geographical origin of the virus isolates in Iran. However, Jung et al. (2002) reported that the TMV potato isolates were different on basis of geographical locations.

Based on above results, it can be concluded that TMV cucumber isolate was able to infect similar indicator host plants to tobacco isolate, but considerable differences were found in the symptom expressions by each isolate. The differences of symptom expressions might be related to the differences of amino acids in $\mathrm{CP}$ gene among the two isolates. TMV cucumber isolate has deduced amino acids differ from tobacco isolate and it was supported by the phylogenetic tree analysis in which the two isolates were separated in differ clade either based on nucleotide or amino acid sequences.

This article describes the existence of a new variant of TMV infecting cucumber as new host naturally; TMV extends to infect differ host belongs to Cucurbitaceae. It will imply to increase the difficulty to manage the virus in the fields. It is necessary to study the existence of TMV on other crops, their biological and genetic variabilities and integrated management strategies to mitigate TMV infection and distribution in Indonesia.

\section{ACKNOWLEDGEMENTS}

This research was funded by PMDSU program provided by the Ministry of Research, Technology and Higher Education of the Republic of Indonesia for TAD and team through PMDSU Scheme with contract no. 129/SP2H/PTNBH/ DRPM/2018.

\section{REFERENCES}

Adkins S, Kamenova I, Achor D, Lewandowski DJ. 2003. Biological and molecular characterization of a novel Tobamovirus with a unique host range. Plant Dis 87: 1190-1196.

Aldaoud R, Dawson WO, Jones GE. 1989. Rapid, random evolution of the genetic structure of replicating tobacco mosaic virus populations. Intervirology 30: 227-233.

Alishiri A, Rakhshandehroo F, Zamanizadeh HR, Palukaitis P. 2013. Prevalence of Tobacco mosaic virus in Iran and evolutionary analyses of the coat protein gene. Plant Pathol J 29: 260-273.

Balique F, Colson P, Raoult D. 2012. Tobacco mosaic virus in cigarettes and saliva of smokers. J Clin Virol 55: 374-376.

Bendahmane M, Chen I, Asurmendi S, Bazzini AA, Szecsi J, Beachy RN. 2007. Coat protein-mediated resistance to TMV infection of Nicotiana tabacum involves multiple modes of interference by coat protein. Virology 366: 107-116.

Central Bureau of Statistics. 2017. Vegetable Crop Production in Indonesia 2012-2016. Central Bureau of Statistics, Jakarta. [Indonesian]

Cherian S, Muniyapppa V. 1998. ELISA based survey and host range of Tomato mosaic tobamovirus. Indian J Virol 14: 65-69.

Chitra TR, Prakash HS, Albrechtsen SE, Shetty HS, Mathur SB. 2002. Indexing of leaf and seed samples of tomato and bell pepper for Tobamoviruses. Indian Phytopathol 55: 84-86.

Choi SK, Yoon JY, Chung BN. 2009. Genome analysis and characterization of a Tobacco mosaic virus isolate infecting balsam (Impatiens balsamina). Arch Virol 154: 881-885.

Conti G, Rodriguez MC, Ventutuzzi AL, Asurmendi S. 2017. Modulation of host plant immunity by Tobamovirus proteins. Ann Bot 119: $737-$ 747.
Damiri N. 2014. Mixed viral infection and growth stage on chilli (Capsicum annuum L.) production. Trop Agric Sci 37: 275-283.

Daryono BS, Natsuaki KT. 2009. Survey on the occurrence of viruses infecting cucurbits in Yogyakarta and Central Java. J Perlin Tan Indonesia 15: 83-89. [Indonesian]

Dombrovsky A, Smith E. 2017. Seed transmission of Tobamoviruses: Aspect of Global Disease Distribution. Adv. Seed Biol Chapter 12: 233-260. Edited by Jose C Jimenez Lopez. Intech Open.

Doyle JJ, Doyle JL. 1987. A rapid DNA isolation procedure for small quantities of fresh leaf tissue. Phytochemical Bull 19: 11-15.

El-Baky RMA, El-Azeim NHA, Gad GFM. 2013. Prevalence of extendedspectrum beta-lactamase, ampc betalactamase, and metallo-betalactamase among clinical isolates of Pseudomonas aeruginosa. J Adv Biotechnol 1:22-29.

Gallois JL, Moury B, German-Retana S. 2018. Role of the genetic background in resistance to plant viruses. Int J Mol Sci 19: 1-20.

ICTV [International Committee on Taxonomy of Viruses]. 2012. Virus Taxonomy: Classification and Nomenclature of Viruses. Elsevier Academic Press, London.

Johnson CS, Main CE. 1983. Yield/quality trade-offs of Tobacco mosaic virus-resistant cultivars in relation to disease management. Plant Dis 67: 886-890.

Jung HW, Yun WS, Hahm YI, Kim KH. 2002. Characterization of Tobacco mosaic virus isolated from potato showing yellow leaf mosaic and stunting symptoms in Korea. Plant Dis 86: 112-117.

Kearney CM, Thomson MJ, Roland KE. 1999. Genome evolution of tobacco mosaic virus populations during long-term passaging in a diverse range of hosts. Arch Virol 144: 1513-1526.

Khamphirapaeng P, Cheewangkoon R, McGovern RJ, Wong SM, ToAnun C. 2017. Detection of Tobacco mosaic virus in petunia and tobacco cells using inclusion body staining. Int $\mathrm{J}$ Agric Technol 13:163-168.

Koch C, Wabbel K, Eber FJ, Krolla-Sidenstein P, Azucena C, Gliemann H, Eiben S, Geiger F, Wege C. 2015. Modified TMV particles as beneficial scaffolds to present sensor enzymes. Front Plant Sci 6: 117.

Kumar S, Udaya SAC, Nayaka SC, Lund OS, Prakash HS. 2011. Detection of Tobacco mosaic virus and Tomato mosaic virus in pepper and tomato by multiplex RT-PCR. Lett Appl Microbiol 53: 359-363.

Letschert B, Gunter A, Lesemann DE, Willingmann P, Heinze C. 2002. Detection and differentiation of serologically cross-reacting Tobamoviruses of economically importance by RT-PCR and RTPCR-RFLP. J Virol Methods 106:1-10.

Li Y, Wang Y, Hu J, Xiao L, Tan G, Lan P, Liu Y, Li F. 2017. The complete genome sequence, occurrence and host range of Tomato mottle mosaic virus Chinese isolate. Virol J 14: 1-9.

Listihani, Hidayat SH, Wiyono S, Damayanti TA. 2018. First report of Tobacco mosaic virus on cucumber [Cucumis sativus (L.)] in Java, Indonesia. IOP Conf Ser: Earth Environ Sci 197:012043. DOI :10.1088/1755-1315/197/1/012043

Luria N, Smith E, Reingold V, Bekelman I, Moshe L, Levin I, Elad N, Tam Y, Sela N, Abu-ras A, Ezra N, Haberman A, Yitzhak L, Lachman O, Dombrovsky A. 2017. A new Israeli Tobamovirus isolate infects tomato plants harboring Tm-22 resistance genes. PLoS One 17: 1-19.

Mahendra IBD, Phabiola TA, Yuliadhi KA. 2017. Effect of virus infection several types of decreased production plant tomato (Lycopersicum esculentum) in Kerta Village, Payangan District, Gianyar Regency. J Trop Agroecotech 6: 301-309.

Nassar EA, El-Dougdoug KA, Osman ME, Dawoud RA, Kinawy AH. 2012. Characterization and elimination of a TMV isolate infecting chrysanthemum plants in Egypt. Int J Virol 8: 14-26.

Rakhshandehroo F, Hashemi SS, Shahraeen N. 2018. Phylogenetic analysis and genetic structure of new isolates of Tomato mosaic virus in Iran. J Plant Protec Res 58: 25-35.

Rao L, Guo Y, Zhang L, Zhou X, Hong J, Wu J. 2017. Genetic variation and population structure of Cucumber green mottle mosaic virus. Arch Virol 5: 1-10.

Somowiyarjo S, Hartono S, Sulandari S, Putri SU. 2016. Molecular identification of Tobacco mosaic virus on orchid plants in Sleman, Yogyakarta. J Fitopatol Indones 12: 69-73. [Indonesian]

Tamura K, Stecher G, Peterson D, Filipski A, Kumar S. 2013. MEGA6: Molecular evolutionary genetics analysis version 6.0. Mol Biol Evol 30: $2725-2729$. 